\title{
Obtaining bitumen from paraffinic-base crude via joint oxidation of tar and different products of oil processing
}

\author{
Andriy Nagurskyy ${ }^{1}$, Bohdan Korchak ${ }^{2}$ \\ 1. Department of Chemical Engineering, Lviv Polytechnic National University, UKRAINE, Lviv, \\ S. Bandery street 12, E-mail: andrii.o.nahurskyi@lpnu.ua \\ 2. Department of Civil Safety, Lviv Polytechnic National University, UKRAINE, Lviv, S. Bandery street 12, \\ E-mail: kor4ak93@gmail.com
}

\begin{abstract}
Petroleum bitumen has been obtained via oxidation of tar produced from paraffin-base crude and via joint oxidation of tar and dark petroleum resin, pyrolysis heavy resin and neutralized acid tar.
\end{abstract}

Keywords - tar, paraffin-base crude, bitumen, oxidation, modification.

\section{Introduction}

Petroleum bitumen production is one of the priority directions of oil refining. Recently the more strict demands for the quality of petroleum bitumen are made especially for their mechanical and deformational properties, thermooxidative resistance, etc [1]. The bad quality of crude, namely the residuals of paraffin-base crude, is the main problem of bitumen production. It is the especially urgent problem for bitumen producers in Ukraine because the main part of oil produced in this country is the paraffinic-base crude [2].

The aim of this work was to examine the production of high-quality petroleum bitumen on the basis of parrafinic oil residuals and study the joint oxidation of residuals with different additives.

\section{Experimental}

The tar obtained while West-Ukrainian paraffinic crude processing was used as a raw material. Its characteristic is given in Table 1. The initial material has a high content of oil components and paraffinic hydrocarbons and refers to the colloidal structure of "gel" type characterized by insufficient content of resins and polycyclic aromatics. It is considered as bad crude for bitumen production.

Table 1

Characteristics of the initial tar and oxidated bitumen

\begin{tabular}{|c|c|c|}
\hline \multicolumn{1}{|c|}{ Index } & Tar & Oxidated bitumen \\
\hline Softening temperature, ${ }^{\circ} \mathrm{C}$ & 42 & 46 \\
\hline Penetration at $25^{\circ} \mathrm{C}, 0.1 \mathrm{~mm}$ & 245 & 163 \\
\hline Ductility at $25^{\circ} \mathrm{C}, \mathrm{cm}$ & 13 & 14 \\
\hline Group composition, wt\%: & & \\
asphaltenes & 19.60 & 22.37 \\
resins & 24.38 & 24.63 \\
oils & 56.02 & 53.00 \\
including paraffines & 5.42 & 5.36 \\
\hline
\end{tabular}

The investigations were carried out by two directions: the initial tar oxidation and joint oxidation of the initial tar with other components. The main regularities of the oxidated bitumen obtaining have been studied. The following indexes were determined for the obtained product: softening temperature, ductility and penetration. Table 1 contains the characteristics of bitumen obtained via paraffinic tar oxidation at $250{ }^{\circ} \mathrm{C}$, air consumption of $2.5 \mathrm{~min}^{-1}$ for $6 \mathrm{~h}$.

The obtained oxidated bitumen is characterized by low ductility and high penetration that is irregular for commercial bitumen. Such results are explained by inadequate group composition of obtained bitumen. Moreover, the obtained bitumen is characterized by high content of paraffinic 
hydrocarbons which are inert while oxidation, worsen the ductility, decrease the plasticity temperature interval and worsen the bitumen strength and adhesion.

To intensify the bitumen obtaining we studied the main regularities of joint oxidation of tar obtained from paraffinic-base crude and different products of oil processing. The following products were studied as additives for the raw material:

- dark petroleum resin (DPR) - dark-brown substance obtained via thermal oligomerization of pyrolysis heavy resin;

- pyrolysis heavy resin (PHR) - by-product of hydrocarbon crude pyrolysis;

- acid tar - by-product of sulfuric acid refining.

The results of joint oxidation under optimum conditions are presented in Table 2 .

Table 2

Effect of initial tar additives on the obtaining of petroleum bitumen

\begin{tabular}{|c|c|c|c|c|c|}
\hline \multicolumn{3}{|c|}{ Joint oxidation conditions } & \multicolumn{3}{|c|}{ Petroleum bitumen characteristics } \\
\hline $\begin{array}{l}\text { Time, } \\
\mathrm{h}\end{array}$ & $\begin{array}{l}\text { Air } \\
\text { consumption, } \\
\min ^{-1}\end{array}$ & $\begin{array}{l}\text { Temperature, } \\
{ }^{\circ} \mathrm{C}\end{array}$ & $\begin{array}{l}\text { Softening } \\
\text { temperature, }{ }^{\circ} \mathrm{C}\end{array}$ & $\begin{array}{l}\text { Penetration at } \\
25^{\circ} \mathrm{C}, 0.1 \mathrm{~mm}\end{array}$ & $\begin{array}{l}\text { Ductility at } \\
25^{\circ} \mathrm{C}, \mathrm{cm}\end{array}$ \\
\hline \multicolumn{6}{|c|}{ Additive - DPR in amount of $7.5 \mathrm{wt} \%$} \\
\hline 6 & 2.5 & 250 & 55 & 59 & 21 \\
\hline \multicolumn{6}{|c|}{ Additive - PHR in amount of $5 \mathrm{wt} \%$} \\
\hline 9 & 2.5 & 250 & 49 & 102 & 35 \\
\hline \multicolumn{6}{|c|}{ Additive - neutralized acid tar in amount of $20 \mathrm{wt} \%$} \\
\hline 6 & 2.5 & 250 & 52 & 97 & 9 \\
\hline
\end{tabular}

The addition of DPR increases the softening temperature and ductility and decreases penetration. Moreover, the DPR introduction intensifies oxidation process and reduces oxidation time. While using PHR it is possible to increase the degree of crude "aromatization" and oxidation intensity. The paraffinic hydrocarbons which are inert ones are oxidized in a higher degree in the presence of aromatics. Bitumen obtained using PHR are characterized by higher hardness, refractoriness and plasticity compared with bitumen on the basis of only paraffinic tar.

The addition of neutralized acid tar allows to increase the softening temperature and decrease the bitumen penetration. It is important that acid tar, which is a large-tonnage waste product, may be ably utilized.

\section{Conclusion}

Bitumen obtained via oxidation of tar produced from Ukrainian paraffin-base crude has operational properties which do not fulfill requirements for road bitumen. While using petroleum resin or pyrolysis heavy resin in amount of 5-7.5 wt \% for joint oxidation with paraffinic tar it is possible to intensify oxidation, reduce oxidation time, increase bitumen hardness and refractoriness and improve plasticity.

\section{References}

[1] Iryna Fryder, Serhiy Pysh'yev, Oleh Grynyshyn (2013). Gas condensate residual usage for oxidated bitumen production. Chemistry \& Chemical Technology, Vol.7, №1, 105-108. https://doi.org/10.23939/chcht07.01.105

[2] Andriy Nagurskyy, Yuriy Khlibyshyn, Oleg Grynyshyn, Victoria Kochubei (2020). Rubber crumb modified bitumen produced from residuals of crude oils of ukrainian deposits. Chemistry \& Chemical Technology, Vol.14, №3, 420-425. https://doi.org/10.23939/chcht14.03.420 